\title{
Correction to: An Investigation into Language Learners' L2WTC by Casting a New Look at Feedback Through the Lenses of Life-Responsive Approach to Language Teaching
}

\author{
Haniyeh Jajarmi ${ }^{1} \cdot$ Sahar Tabatabaee Farani $^{1} \cdot$ Shaghayegh Shayesteh $^{1}$ \\ Published online: 13 February 2020 \\ (C) National Taiwan Normal University 2020
}

\section{Correction to: English Teaching \& Learning (2019) 43:337-351 https://doi.org/10.1007/s42321-019-00031-4}

The title and keywords in the original publication are in Simplified Chinese rather than Traditional Chinese. Please find here the title, abstract, and keywords in Traditional Chinese.

透過生活回應式語言教學法重新審視反饋以探究語言學習者的二語溝通意願

\section{摘要}

語言課程的最終目標，且人文心理學觀點亦認為生活品質得以藉由教育而有所提高。立基 於上面兩個觀點, 本研究提出了名為「生活反饋」的新型反饋形式, 並探究這種反饋形式能在 提高語言學習者溝通意願(WTC)的面向上有多少程度的助益。

本研究招募了 20 名語言教師和 324 名學生, 並應用了質、量混合分析方法來檢驗本研究資 料。在質性資料搜集階段, 我們對各個課程中的討論進行了 30 分鐘的觀課, 並根據教師給學生 的反饋類型(生活反饋或語言反饋)將教師分為生活教師與語言教師兩類。在量話資料搜集階

The online version of the original article can be found at https://doi.org/10.1007/s42321-019-00031-4

Shaghayegh Shayesteh

shaghayegh.shayesteh@gmail.com

Haniyeh Jajarmi

hjajarmi@yahoo.com

Sahar Tabatabaee Farani

sahar.tabatabaee1983@gmail.com

1 Faculty of Letters \& Humanities, Ferdowsi University of Mashhad, Park Sq., Mashhad, Iran 
段, 我們則對學習者進行了溝通意願的問卷調查。我們使用了獨立樣本t檢驗來分析數據。就 總體結果來說, 相較於提供(較多)語言反饋的教師, 提供學習者生活反饋的教師更能促進學習 者的溝通意願。本研究亦就此新型反饋形式進行討論並提出其在語言教育上的教學暗示。

關鍵詞:糾正反饋、溝通意願、應用英語教學、生活反饋、生活回應式語言教學法 